\title{
Carotenoid and vitamin intake, von Hippel-Lindau gene mutations and sporadic renal cell carcinoma
}

Citation for published version (APA):

van Dijk, B. A., Schouten, L. J., Oosterwijk, E., Hulsbergen van de Kaa, C. A., Kiemeney, L. A., Goldbohm, R. A., Schalken, J. A., \& van den Brandt, P. A. (2008). Carotenoid and vitamin intake, von Hippel-Lindau gene mutations and sporadic renal cell carcinoma. Cancer Causes \& Control, 19(2), 125134. https://doi.org/10.1007/s10552-007-9078-5

Document status and date:

Published: 01/01/2008

DOI:

10.1007/s10552-007-9078-5

Document Version:

Publisher's PDF, also known as Version of record

\section{Please check the document version of this publication:}

- A submitted manuscript is the version of the article upon submission and before peer-review. There can be important differences between the submitted version and the official published version of record.

People interested in the research are advised to contact the author for the final version of the publication, or visit the DOI to the publisher's website.

- The final author version and the galley proof are versions of the publication after peer review.

- The final published version features the final layout of the paper including the volume, issue and page numbers.

Link to publication

\footnotetext{
General rights rights.

- You may freely distribute the URL identifying the publication in the public portal. please follow below link for the End User Agreement:

www.umlib.nl/taverne-license

Take down policy

If you believe that this document breaches copyright please contact us at:

repository@maastrichtuniversity.nl

providing details and we will investigate your claim.
}

Copyright and moral rights for the publications made accessible in the public portal are retained by the authors and/or other copyright owners and it is a condition of accessing publications that users recognise and abide by the legal requirements associated with these

- Users may download and print one copy of any publication from the public portal for the purpose of private study or research.

- You may not further distribute the material or use it for any profit-making activity or commercial gain

If the publication is distributed under the terms of Article $25 \mathrm{fa}$ of the Dutch Copyright Act, indicated by the "Taverne" license above, 


\title{
Carotenoid and vitamin intake, von Hippel-Lindau gene mutations and sporadic renal cell carcinoma
}

\author{
Boukje A. C. van Dijk · Leo J. Schouten · Egbert Oosterwijk • \\ Christina A. Hulsbergen-van de Kaa • Lambertus A. L. M. Kiemeney • \\ R. Alexandra Goldbohm · Jack A. Schalken · Piet A. van den Brandt
}

Received: 10 January 2007 / Accepted: 4 October 2007 / Published online: 9 November 2007

(C) Springer Science+Business Media B.V. 2007

\begin{abstract}
Objective We investigated whether dietary carotenoid and vitamin intake and supplemental vitamin use were inversely associated with RCC risk and with Von HippelLindau (VHL)-gene mutations in clear-cell renal cell carcinoma (RCC).

Methods The Netherlands Cohort Study on diet and cancer (NLCS) includes 120,852 persons, who completed a self-administered food-frequency questionnaire in 1986. After 11.3 years of follow-up, 284 cases and a random sample of 4,095 persons (subcohort) with complete data
\end{abstract}

B. A. C. van Dijk - L. J. Schouten - P. A. van den Brandt Department of Epidemiology, NUTRIM, Maastricht University, Maastricht, The Netherlands

Present Address:

B. A. C. van Dijk $(\bowtie)$

Department of Clinical Chemistry 441, Radboud University

Nijmegen Medical Centre, P.O. Box 9101, 6500, HB,

Nijmegen, The Netherlands

e-mail: b.vandijk@akc.umcn.nl

E. Oosterwijk - L. A. L. M. Kiemeney · J. A. Schalken Department of Urology, Radboud University Nijmegen

Medical Centre, Nijmegen, The Netherlands

C. A. Hulsbergen-van de Kaa

Department of Pathology, Radboud University Nijmegen

Medical Centre, Nijmegen, The Netherlands

L. A. L. M. Kiemeney

Department of Epidemiology and Biostatistics,

Radboud University Nijmegen Medical Centre, Nijmegen,

The Netherlands

R. A. Goldbohm

Department of Food and Chemical Risk Analysis, TNO

Nutrition and Food Research, Zeist, The Netherlands were included in multivariable analyses using a case-cohort approach. $V H L$ gene mutational analysis was complete for 225 cases. Rate ratios and corresponding 95\% confidence intervals were estimated using Cox proportional hazard models, while adjusting for age, sex, smoking, body mass index, and a history of hypertension.

Results We observed no association for dietary carotenoid and vitamin intake and RCC risk, and a somewhat increased risk with supplemental vitamin $\mathrm{E}, \mathrm{AD}$, and multivitamin use. Results were suggestive of higher RRs for alpha-carotene, beta-cryptoxanthin, folate, and supplemental vitamin $\mathrm{C}$ and multivitamin intake for wildtype $V H L$ tumors compared to $V H L$-mutated tumors.

Conclusions There was no association of carotenoid, vitamin or supplemental vitamin intake and RCC risk. These associations should be investigated by others to confirm the current observations.

Keywords Renal cell carcinoma - Vitamins ·

Carotenoids - Supplements .

von Hippel-Lindau gene mutations · Netherlands .

Cohort study

\section{Introduction}

Mutations in the von Hippel-Lindau (VHL) gene are believed to be an early event in renal carcinogenesis. $V H L$ mutations are mainly observed in tumors of the most common histological subtype, clear-cell renal cell carcinoma (RCC) [1]. Mutations are observed in the entire gene and usually lead to a truncated inactive protein [1]. The $V H L$ gene is a tumor suppressor gene involved in cell cycle regulation, regulation of hypoxia inducible genes and proper fibronectin assembly in 
extracellular matrix $[2,3]$. It is estimated that $56-69 \%$ [2] of clear-cell renal tumors harbor a mutation in the $V H L$ gene.

Occupational exposure to trichloroethylene $[4,5]$ and consumption of citrus fruit and vegetables (confined to smokers) [6] have been linked to VHL gene mutations in RCC in previous studies [4-6]. There is some evidence that the intake of vegetables, selenium and particularly citrus fruit protects the renal $V H L$ gene from mutational insults, although chance results could not be ruled out [6]. To our knowledge, there are no other reports on an association of fruits and vegetables, or the more specific carotenoids and vitamin intake, and VHL gene mutations published thus far.

Generally, intake of carotenoids and vitamins are considered to be protective of cancer, mainly due to their ascribed anti-oxidant capacities [7]. In a study by Nyberg et al., diet and smoking habits were linked to somatic mutations in vivo [8]. The mutant frequency was significantly decreased in relation to vitamin $\mathrm{C}$ intake, while a u-shaped association with higher mutation frequencies at lower and higher intakes was observed with dietary carotenoid intake [8]. Dietary antioxidants take part in cellular reduction-oxidation (redox) reactions in which they can act as either antioxidants (electron donors) or prooxidants (electron acceptors), depending on the physiological environment and general oxidative state [9]. Thus, the possibility exists that, in an environment resulting in prooxidant activity by dietary antioxidants, antioxidant supplementation may actually cause harm in terms of increased risk of new disease [9].

A limited number of epidemiological studies, of which two were cohort studies, investigated the association of carotenoids and vitamins and risk of RCC [10-21]. These studies showed inverse or null associations but results of these studies never consistently pointed to a null or inverse association.

We investigated whether dietary carotenoid (alphacarotene, beta-carotene, lutein + zeaxanthine, beta-cryptoxanthine, and lycopene), and vitamin (vitamins A (retinol), C, E, and folate) intake and supplemental vita$\min \mathrm{C}, \mathrm{E}, \mathrm{AD}$, and multivitamin use were associated with sporadic RCC in a prospective cohort study. Furthermore, we investigated the association with $V H L$ gene mutations in clear-cell RCC, which may explain the inconsistent results observed in the past. Stratified analyses by smoking were also carried out since a differential effect by smoking status has been suggested for the association of citrus fruits and RCC and VHL gene mutations [6], and for the association of some carotenoids and vitamins and RCC [14].

\section{Subjects and methods}

\section{Netherlands Cohort Study}

The Netherlands Cohort Study on diet and cancer (NLCS) was started in September 1986. The study design has been reported in detail elsewhere [22]. Briefly, the cohort included 120,852 men and women aged 55-69 years in 1986. The study was designed as a case-cohort study, using all cases and a random sample of 5,000 persons from the cohort (subcohort), who have been followed for vital status information to estimate the accumulated person-years in the entire cohort [23].

Follow-up for incident cancers and vital status

The entire cohort was followed for incident cancer by computerized record linkage with the Netherlands Cancer Registry and PALGA, a national database of pathology reports. All participants who reported prevalent cancer (excluding skin cancer) at baseline were excluded from analyses (leaving 4,774 subcohort members). The method of record linkage to obtain information on cancer incidence has been described previously [24]. The completeness of cancer follow-up was estimated to be more than 96\% [25]. From 1986 to 1997 (11.3 years follow up), 355 kidney cancer cases (ICD-O-3: C64.9) were identified. Urothelial cell carcinomas were excluded and only histologically confirmed epithelial cancers were included (ICD-O: M8010-8119, 8140-8570), leaving 337 cases.

The subcohort has been followed up for vital status information biennially by mail. The vital status of subcohort members who did not respond, was completed by contacting municipal population registries. Only two male subcohort members were lost to follow-up after 11.3 years of follow-up.

\section{Questionnaire}

At baseline, all cohort members completed a mailed, selfadministered questionnaire on dietary habits, lifestyle, smoking, personal and family history of cancer and demographic data [26]. The questionnaire concentrated on the habitual consumption of food and beverages during the year preceding the start of the study. The dietary section of the questionnaire was a 150-item semi-quantitative foodfrequency questionnaire, which was validated against 3-day diaries completed at three time points during a calendar year [26]. The correlation, adjusted for error index and day-to-day variation, between the record and the 
questionnaire was estimated at 0.76 for vitamin $\mathrm{A}$ intake and at 0.58 for vitamin $C$ intake [26].

Mean daily nutrient intakes were calculated using the computerized Dutch food composition table [27]. For calculation of the intake of specific carotenoids, an additional food composition table has been constructed [28], providing information on alpha-carotene, beta-carotene, lutein + zeaxanthine, beta-cryptoxanthine, and lycopene. Briefly, foods that are the main sources of carotenoids (e.g., vegetables) and some other foods were sampled and analyzed for alpha-carotene, beta-carotene, lutein, zeaxanthin, and lycopene. Values for all other foods were mostly derived from recent literature with the same methods of analysis used. In the carotenoid food composition table, lutein and zeaxanthin had to be taken together because most of the literature sources did not provide separate values for each of these carotenoids [28]. Folate data were derived from a validated liquid chromatography trienzyme method [29], used to analyze the 125 most important Dutch foods contributing to folate intake [30].

Information on supplement use was collected with an open-ended question with space for four different supplements at most. Participants were asked whether they used vitamin tablets, drops, or other preparations during the 5 years before baseline [31]. The relative validity of this open-ended question was studied in comparison to reference information from three personal interviews carried out within a period of 10 months [32]; recall for overall vitamin supplement use was $72.7 \%$ [32]. In that study, vitamin supplement use included vitamin A, C, AD, B1, B2, B6, $\mathrm{B} 12, \mathrm{~B}$ complex, $\mathrm{E}$ and multivitamin intake. In the current study, we investigated supplemental vitamin C, E, A and/ or $\mathrm{D}(\mathrm{AD})$ and multivitamin intake.

\section{VHL gene mutation analysis}

Paraffin material of cancer cases was collected after approval by the Medical Ethical Committees of Maastricht University, PALGA and the Netherlands cancer registry. We were able to collect paraffin blocks of tumors for 251 cases from 51 pathology laboratories, which we described in detail elsewhere [33].

One experienced pathologist (CAHK) revised all HEstained slides. The RCC were classified according to the World Health Organization (WHO) classification of Tumours of 2002 [34]. DNA isolation and mutation analyses have been described previously. Briefly, paraffin was removed with xylene and DNA was extracted by salt-precipitation. The entire gene was amplified using six primer sets. Samples were first subjected to PCR-SSCP analysis, which was followed by direct sequencing in case of aberrant or equivocal results. Mutations were identified by visual inspection of sequences provided by the ABI basecaller. After revision and VHL gene mutation analyses, data was available for 235 cases [33]. Information for 10 cases was discarded, since the dietary data for these subjects was incomplete or inconsistent according to criteria published before [26].

\section{Statistical analysis}

Based on the literature and previous analyses, considered confounders were age at baseline (years), sex, body mass index $\left(\mathrm{kg} / \mathrm{m}^{2}\right)$, a history of hypertension (yes/no), a family history of RCC (yes/no), alcohol consumption (g/day), social economic status (SES) based on education, nonoccupational physical activity $(<30,30-60,60-90$, $>90 \mathrm{~min} /$ day), occupational physical activity (for men only) $(<8,8-12,>12 \mathrm{~kJ} / \mathrm{min}$ ), and energy intake (kcal/ day). Those variables that were associated with RCC and were correlated with one of the carotenoids or vitamins were included as covariates in multivariable analyses. Confounders entered in these multivariable analyses were age, sex, smoking, BMI, and a history of hypertension.

Differences in age, sex, smoking status, BMI, and a history of hypertension between cases with $(N=225)$ and without $(N=89)$ collected tumor material were assessed by calculating student $t$-tests and chi-square tests.

RRs were calculated for the dietary intake of carotenoids alpha-carotene, beta-carotene, lutein + zeaxanthine, betacryptoxanthine and lycopene, and of the vitamins A (retinol), C, E, and folate. Exposure variables were categorized into quintiles based on the distribution in the subcohort, for men and women separately. For vitamin C, however, quintiles 2 and 3 and quintiles 4 and 5 were combined, because the validation study demonstrated that these quintiles could not be distinguished [26]. Furthermore, we investigated use of supplemental vitamin $\mathrm{C}, \mathrm{E}, \mathrm{AD}$ and multivitamins (yes or no).

Analyses were carried out for the following case groups with complete data: total RCC (all cases of RCC detected by linkage to cancer and pathology registry; $N=284$ ); clear-cell RCC (all cases of RCC with collected tumor material and classified as clear-cell after revision by one experienced pathologist (CAHK); $N=162)$; VHL mutated clear-cell RCC (clear-cell RCC with a mutation in the $V H L$ gene; $N=97$ ) and $V H L$ wildtype clear-cell RCC (clear-cell RCC without a mutation in the VHL gene; $N=65)$.

RRs and corresponding 95\% confidence intervals (CI) were estimated using Cox proportional hazard models processed with STATA (STATA statistical software, Release 7, STATA Corporation, College Station, TX, USA, 2001), after testing the proportional hazards assumption using scaled Schoenfeld residuals [35]. 
Standard errors were estimated using the robust HuberWhite sandwich estimator to account for additional variance introduced by sampling from the cohort [36]. To obtain $p$-values for dose-response trends, ordinal exposure variables were fitted as continuous terms. Two sided $p$-values are reported throughout this paper.

\section{Results}

Baseline characteristics for exposure variables and potential confounders for subcohort members, all cases, cases with collected tumor material, clear-cell cases and clearcell cases with or without a VHL gene mutation are shown in Table 1. First, we checked for differences in characteristics of RCC cases for whom we could $(N=225)$ or could not $(N=89)$ collect tumor tissue. There were no differences in mean age $(p=0.62)$, the percentage of men $(p=0.16)$, the percentage of smokers (never, ex and current) $(p=0.33)$, mean BMI $(p=0.85)$, or the percentage of cases that reported a history of hypertension $(p=0.71)$.

We also tested differences in mean carotenoid and vitamin intake and in the percentage of supplement users between clear-cell RCC with and without a VHL gene mutation. There were no remarkable differences in mean carotenoid and vitamin intake between clear-cell RCC with and clear-cell RCC without a VHL gene mutation (results not shown). The percentage of supplemental vitamin $\mathrm{C}$ and multivitamin users was higher for clear-cell RCC with wildtype VHL compared to clear-cell RCC with a $V H L$ gene mutation. (10.1\% versus $4.6 \%$ and $10.1 \%(p=0.15)$ versus $3.6 \%(p=0.08)$, respectively), although these differences were statistically not significant.

Rate ratios for the association of carotenoids, vitamins, and supplement use and total RCC, clear-cell RCC and clear-cell RCC with or without $V H L$ gene mutations are shown in Table 2. A statistically significant inverse association with RCC was observed in quintile 2 of lutein + zeaxanthin intake. Furthermore, a statistically significant increased risk of RCC was observed in quintile 4 of beta-cryptoxanthin intake. The lowest rate ratios seem to be present in the middle quintiles (Q2-4) for carotenoids, with the exception of beta-cryptoxanthin and lycopene. Higher intakes of beta-cryptoxanthin and lycopene were associated with an increased RCC risk. The observed rate ratios for wildtype $V H L$ tumors were higher than those observed for $V H L$ mutated tumors in case of dietary alpha-carotene and beta-cryptoxanthin intake (Table 2). Vitamin intake did not seem to be associated with RCC risk, but there was a possible differential effect for folate intake between tumors with and without a VHL gene mutation. Rate ratios were mostly greater than 1 in case of wildtype $V H L$ tumors, while these were mostly lower than 1 for $V H L$ mutated tumors. Supplemental vitamin $\mathrm{E}, \mathrm{AD}$ and multivitamin use were associated with increased RCC risk, while there was no association of supplemental vitamin $\mathrm{C}$ use and RCC risk. Stratified analyses based on VHL mutational status revealed higher RRs for wildtype tumors in case of supplemental vitamin C and multivitamin use and lower RRs for wildtype tumors in case of supplemental vitamin E and AD use. Supplemental multivitamin use was associated with a statistically significant increased risk of clear-cell tumors without a $V H L$ gene mutation (RR: 2.51 ; 95\% CI: 1.10-5.75).

We also investigated possible interaction by sex and cigarette smoking status. Although we observed a statistically significant interaction of sex and beta-carotene intake for RCC $(p=0.03)$, stratified analyses showed that there was no consistent differential effect for sex over the quintiles (results not shown). $P$-values for interaction by smoking (never, ex and current smokers) ranged from 0.17 for folate to 0.85 for supplemental vitamin $\mathrm{E}$ use in multivariable analyses. We repeated these analyses for the subgroups of clear-cell cases with or without a $V H L$ gene mutation. No conclusions could be drawn based on these results since the low number of cases, especially in the supplemental vitamin use groups, hampered analyses (results not shown).

\section{Discussion}

We investigated the association of several dietary carotenoids and vitamins (A, C, E, and folate) and supplemental vitamin $\mathrm{C}, \mathrm{E}, \mathrm{AD}$ and multivitamin use and $\mathrm{RCC}$ incidence in the NLCS. We observed no association for carotenoids and vitamins from diet and RCC risk. This is not surprising, since we also observed null associations for vegetable and fruit consumption and RCC risk [37]. Contrary to expectations, we observed a small statistically non-significant increased risk with supplemental vitamin $\mathrm{E}, \mathrm{AD}$, and multivitamin use.

Important strengths from the NLCS are that exposure was assessed before the diagnosis of cancer and that only incident cases were included. Therefore, recall bias is not likely to have influenced our results. Furthermore, selection bias is also unlikely because of the high completeness of follow-up of cases and subcohort members.

The consumption of vegetables and fruits, which contribute the most to the intake of carotenoids and vitamins, was extensively measured in the NLCS, using a validated semi-quantitative food-frequency questionnaire. In a reproducibility study, it was further demonstrated that the single food frequency questionnaire measurement could characterize dietary habits for a period of at least 5 years [38]. Misclassification of exposure may have occurred. 


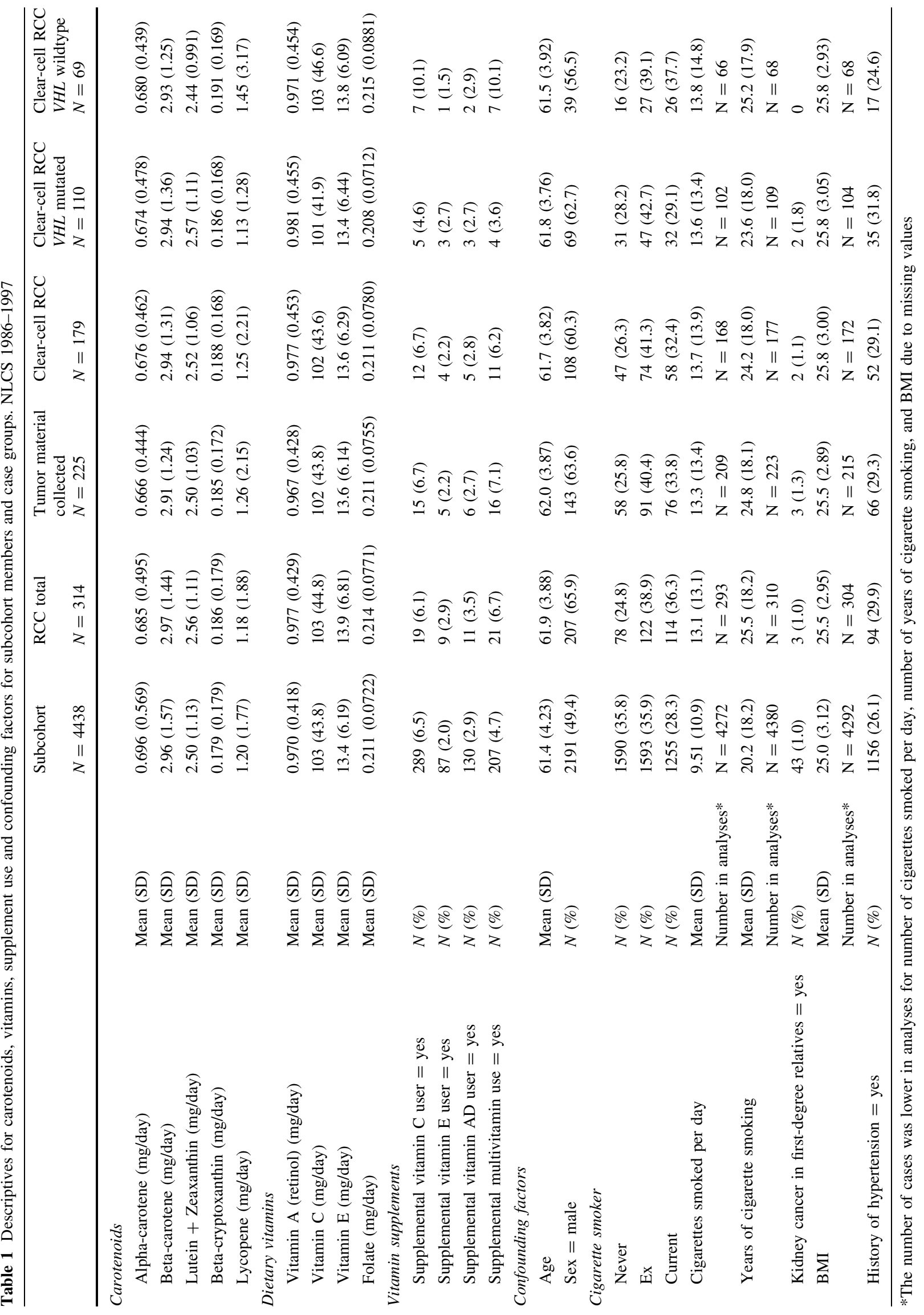


Table 2 Relative risks for the association of dietary carotenoid and vitamin intake, and supplemental vitamin use and Renal Cell Carcinoma (RCC), clear-cell RCC and clear-cell RCC with or without a von Hippel-Lindau gene mutation, NLCS 1986-1997

\begin{tabular}{|c|c|c|c|c|c|}
\hline Carotenoid/vitamin & $\begin{array}{l}\text { Median intake } \\
\text { in subcohort } \\
\text { Men/women }\end{array}$ & $\begin{array}{l}\text { RCC } \\
\text { RR }(95 \% \mathrm{CI})\end{array}$ & $\begin{array}{l}\text { Clear-cell RCC } \\
\text { RR }(95 \% \mathrm{CI})\end{array}$ & $\begin{array}{l}\text { Clear-cell RCC } \\
V H L \text { gene mutated } \\
\text { RR }(95 \% \text { CI })\end{array}$ & $\begin{array}{l}\text { Clear-cell RCC } \\
\text { wildtype } \\
\text { RR }(95 \% \mathrm{CI})\end{array}$ \\
\hline Number of cases & & 284 & 162 & 97 & 65 \\
\hline Number person-years in subcohort & & 42972 & 42972 & 42972 & 42972 \\
\hline \multicolumn{6}{|l|}{ Alpha-carotene } \\
\hline Q1 & $0.19 / 0.18$ & 1 (reference) & 1 (reference) & 1 (reference) & 1 (reference) \\
\hline Q2 & $0.38 / 0.37$ & $0.85(0.59-1.24)$ & $0.81(0.49-1.34)$ & $0.67(0.35-1.28)$ & $1.07(0.48-2.38)$ \\
\hline Q3 & $0.57 / 0.56$ & $0.82(0.56-1.20)$ & $0.97(0.60-1.57)$ & $0.93(0.51-1.68)$ & $1.04(0.47-2.32)$ \\
\hline Q4 & $0.82 / 0.82$ & $0.76(0.52-1.12)$ & $0.76(0.45-1.26)$ & $0.61(0.31-1.17)$ & $1.05(0.47-2.34)$ \\
\hline Q5 & $1.31 / 1.32$ & $0.90(0.62-1.31)$ & $0.96(0.59-1.57)$ & $0.84(0.45-1.55)$ & $1.20(0.54-2.65)$ \\
\hline P-trend & & 0.46 & 0.80 & 0.53 & 0.71 \\
\hline Continuous per $0.1 \mathrm{mg} / \mathrm{day}$ & & $0.99(0.97-1.01)$ & $0.98(0.96-1.01)$ & $0.98(0.95-1.02)$ & $0.99(0.95-1.03)$ \\
\hline \multicolumn{6}{|l|}{ Beta-carotene } \\
\hline Q1 & $1.48 / 1.39$ & 1 (reference) & 1 (reference) & 1 (reference) & 1 (reference) \\
\hline Q2 & $2.14 / 2.03$ & $0.76(0.51-1.12)$ & $0.92(0.54-1.55)$ & $0.89(0.45-1.74)$ & $0.96(0.43-2.17)$ \\
\hline Q3 & $2.67 / 2.61$ & $0.84(0.57-1.23)$ & $1.22(0.74-2.01)$ & $1.26(0.67-2.36)$ & $1.17(0.53-2.56)$ \\
\hline Q4 & $3.37 / 3.32$ & $0.84(0.57-1.23)$ & $1.01(0.61-1.69)$ & $1.09(0.58-2.07)$ & $0.89(0.39-2.04)$ \\
\hline Q5 & $4.75 / 4.72$ & $0.97(0.67-1.40)$ & $1.09(0.66-1.82)$ & $0.94(0.48-1.83)$ & $1.34(0.62-2.89)$ \\
\hline P-trend & & 0.95 & 0.64 & 0.92 & 0.54 \\
\hline Continuous per $1 \mathrm{mg} /$ day & & $0.98(0.91-1.06)$ & $0.96(0.87-1.05)$ & $0.95(0.84-1.07)$ & $0.98(0.85-1.12)$ \\
\hline \multicolumn{6}{|l|}{ Lutein + Zeaxanthin } \\
\hline Q1 & $1.42 / 1.30$ & 1 (reference) & 1 (reference) & 1 (reference) & 1 (reference) \\
\hline Q2 & $1.89 / 1.81$ & $0.66(0.45-0.99)$ & $0.68(0.41-1.13)$ & $0.57(0.28-1.14)$ & $0.84(0.40-1.79)$ \\
\hline Q3 & $2.37 / 2.29$ & $0.79(0.54-1.16)$ & $0.81(0.49-1.31)$ & $0.78(0.41-1.46)$ & $0.85(0.40-1.79)$ \\
\hline Q4 & $2.86 / 2.78$ & $0.92(0.64-1.33)$ & $0.99(0.62-1.58)$ & $1.12(0.63-2.02)$ & $0.79(0.37-1.68)$ \\
\hline Q5 & $3.89 / 3.77$ & $0.90(0.62-1.29)$ & $0.76(0.46-1.25)$ & $0.76(0.40-1.45)$ & $0.76(0.35-1.63)$ \\
\hline P-trend & & 0.88 & 0.74 & 0.89 & 0.48 \\
\hline Continuous per $1 \mathrm{mg} /$ day & & $1.01(0.91-1.12)$ & $0.96(0.84-1.10)$ & $0.98(0.81-1.17)$ & $0.94(0.76-1.15)$ \\
\hline \multicolumn{6}{|l|}{ Beta-cryptoxanthin } \\
\hline Q1 & $0.01 / 0.03$ & 1 (reference) & 1 (reference) & 1 (reference) & 1 (reference) \\
\hline Q2 & $0.04 / 0.09$ & $1.08(0.72-1.62)$ & $1.24(0.72-2.13)$ & $1.00(0.52-1.93)$ & $1.88(0.73-4.82)$ \\
\hline Q3 & $0.10 / 0.17$ & $0.99(0.65-1.50)$ & $1.11(0.64-1.93)$ & $0.63(0.30-1.32)$ & $2.40(0.97-5.95)$ \\
\hline Q4 & $0.20 / 0.27$ & $1.56(1.06-2.28)$ & $1.58(0.95-2.65)$ & $1.18(0.63-2.22)$ & $2.64(1.08-6.46)$ \\
\hline Q5 & $0.36 / 0.50$ & $1.17(0.78-1.74)$ & $1.40(0.83-2.36)$ & $1.30(0.70-2.42)$ & $1.61(0.62-4.16)$ \\
\hline P-trend & & 0.11 & 0.11 & 0.31 & 0.18 \\
\hline Continuous per $0.05 \mathrm{mg} /$ day & & $1.03(1.00-1.06)$ & $1.03(0.99-1.07)$ & $1.03(0.98-1.08)$ & $1.03(0.97-1.09)$ \\
\hline \multicolumn{6}{|l|}{ Lycopene } \\
\hline Q1 & $0.14 / 0.17$ & 1 (reference) & 1 (reference) & 1 (reference) & 1 (reference) \\
\hline Q2 & $0.42 / 0.56$ & $0.90(0.59-1.35)$ & $0.68(0.38-1.21)$ & $0.81(0.41-1.63)$ & $0.45(0.16-1.29)$ \\
\hline Q3 & $0.74 / 0.90$ & $1.12(0.76-1.67)$ & $1.21(0.73-2.00)$ & $1.10(0.58-2.09)$ & $1.40(0.64-3.06)$ \\
\hline Q4 & $1.11 / 1.30$ & $1.35(0.93-1.98)$ & $1.47(0.90-2.38)$ & $1.26(0.68-2.36)$ & $1.81(0.86-3.82)$ \\
\hline Q5 & $1.98 / 2.33$ & $1.17(0.79-1.72)$ & $1.23(0.74-2.04)$ & $1.13(0.59-2.16)$ & $1.39(0.64-3.05)$ \\
\hline P-trend & & 0.10 & 0.05 & 0.36 & 0.04 \\
\hline Continuous per $0.5 \mathrm{mg} /$ day & & $1.01(0.88-1.17)$ & $1.05(0.88-1.25)$ & $0.96(0.79-1.18)$ & $1.13(0.89-1.44)$ \\
\hline \multicolumn{6}{|l|}{ Vitamin A (retinol) } \\
\hline Q1 & $0.61 / 0.52$ & 1 (reference) & 1 (reference) & 1 (reference) & 1 (reference) \\
\hline Q2 & $0.81 / 0.70$ & $1.01(0.69-1.48)$ & $0.96(0.58-1.60)$ & $1.11(0.59-2.10)$ & $0.76(0.34-1.72)$ \\
\hline Q3 & $0.95 / 0.84$ & $1.00(0.68-1.47)$ & $1.12(0.69-1.84)$ & $1.14(0.60-2.14)$ & $1.11(0.52-2.36)$ \\
\hline
\end{tabular}


Table 2 continued

\begin{tabular}{|c|c|c|c|c|c|}
\hline Carotenoid/vitamin & $\begin{array}{l}\text { Median intake } \\
\text { in subcohort } \\
\text { Men/women }\end{array}$ & $\begin{array}{l}\text { RCC } \\
\text { RR }(95 \% \mathrm{CI})\end{array}$ & $\begin{array}{l}\text { Clear-cell RCC } \\
\text { RR }(95 \% \mathrm{CI})\end{array}$ & $\begin{array}{l}\text { Clear-cell RCC } \\
V H L \text { gene mutated } \\
\mathrm{RR}(95 \% \mathrm{CI})\end{array}$ & $\begin{array}{l}\text { Clear-cell RCC } \\
\text { wildtype } \\
\text { RR }(95 \% \mathrm{CI})\end{array}$ \\
\hline Q4 & $1.14 / 1.01$ & $0.73(0.48-1.11)$ & $0.75(0.44-1.29)$ & $0.89(0.45-1.75)$ & $0.57(0.23-1.37)$ \\
\hline Q5 & $1.51 / 1.37$ & $1.13(0.78-1.64)$ & $1.05(0.64-1.72)$ & $0.94(0.49-1.81)$ & $1.20(0.58-2.48)$ \\
\hline P-trend & & 0.96 & 0.84 & 0.63 & 0.81 \\
\hline Continuous per $0.1 \mathrm{mg} /$ day & & $0.99(0.96-1.03)$ & $1.00(0.95-1.04)$ & $1.00(0.94-1.05)$ & $1.00(0.94-1.06)$ \\
\hline \multicolumn{6}{|l|}{ Vitamin $C$} \\
\hline Q1 & $52.23 / 58.93$ & 1 (reference) & 1 (reference) & 1 (reference) & 1 (reference) \\
\hline $\mathrm{Q} 2+\mathrm{Q} 3$ & $81.78 / 92.73$ & $1.10(0.78-1.55)$ & $1.04(0.67-1.60)$ & $0.90(0.52-1.56)$ & $1.28(0.65-2.55)$ \\
\hline $\mathrm{Q} 4+\mathrm{Q} 5$ & $129.76 / 140.84$ & $1.01(0.72-1.43)$ & $0.88(0.57-1.38)$ & $0.87(0.50-1.50)$ & $0.91(0.44-1.87)$ \\
\hline P-trend & & 0.99 & 0.48 & 0.63 & 0.58 \\
\hline Continuous per $10 \mathrm{mg} /$ day & & $1.01(0.98-1.04)$ & $0.99(0.96-1.03)$ & $0.99(0.94-1.04)$ & $1.00(0.94-1.06)$ \\
\hline \multicolumn{6}{|l|}{ Vitamin $E$} \\
\hline Q1 & $7.18 / 6.13$ & 1 (reference) & 1 (reference) & 1 (reference) & 1 (reference) \\
\hline Q2 & $10.56 / 8.54$ & $0.77(0.51-1.16)$ & $0.66(0.38-1.15)$ & $0.91(0.46-1.78)$ & $0.35(0.12-0.97)$ \\
\hline Q3 & $13.54 / 11.05$ & $1.09(0.75-1.58)$ & $1.16(0.72-1.88)$ & $1.53(0.84-2.80)$ & $0.69(0.30-1.57)$ \\
\hline Q4 & $17.20 / 14.40$ & $1.04(0.72-1.52)$ & $1.13(0.70-1.81)$ & $0.74(0.37-1.49)$ & $1.63(0.85-3.13)$ \\
\hline Q5 & $23.76 / 19.55$ & $1.00(0.68-1.47)$ & $0.90(0.54-1.50)$ & $1.00(0.52-1.93)$ & $0.76(0.34-1.70)$ \\
\hline P-trend & & 0.53 & 0.63 & 0.81 & 0.30 \\
\hline Continuous per $5 \mathrm{mg} /$ day & & $1.05(0.95-1.15)$ & $1.03(0.90-1.16)$ & $1.00(0.84-1.19)$ & $1.07(0.89-1.27)$ \\
\hline \multicolumn{6}{|l|}{ Folate } \\
\hline Q1 & $0.15 / 0.13$ & 1 (reference) & 1 (reference) & 1 (reference) & 1 (reference) \\
\hline Q2 & $0.18 / 0.16$ & $0.83(0.56-1.24)$ & $0.74(0.44-1.24)$ & $0.62(0.33-1.19)$ & $0.99(0.42-2.34)$ \\
\hline Q3 & $0.21 / 0.19$ & $1.04(0.72-1.52)$ & $1.08(0.74-1.77)$ & $1.02(0.58-1.80)$ & $1.20(0.54-2.66)$ \\
\hline Q4 & $0.25 / 0.22$ & $0.86(0.58-1.27)$ & $0.81(0.49-1.35)$ & $0.52(0.26-1.05)$ & $1.44(0.66-3.14)$ \\
\hline Q5 & $0.31 / 0.27$ & $0.95(0.65-1.40)$ & $0.79(0.48-1.31)$ & $0.65(0.34-1.23)$ & $1.10(0.49-2.48)$ \\
\hline P-trend & & 0.88 & 0.50 & 0.17 & 0.52 \\
\hline Continuous per $0.1 \mathrm{mg} /$ day & & $0.99(0.83-1.19)$ & $0.95(0.73-1.23)$ & $0.88(0.62-1.23)$ & $1.05(0.71-1.53)$ \\
\hline Supplement use & Exposed $(\%)^{*}$ & & & & \\
\hline No & & 1 (reference) & 1 (reference) & 1 (reference) & 1 (reference) \\
\hline Supplemental vitamin $\mathrm{C}$ user $=$ yes & 6.6/6.3/6.8/4.1/10.8 & $0.95(0.57-1.58)$ & $1.07(0.57-2.02)$ & $0.64(0.23-1.75)$ & $1.76(0.79-3.95)$ \\
\hline Supplemental vitamin $\mathrm{E}$ user $=$ yes & $2.0 / 3.2 / 2.5 / 3.1 / 1.5$ & $1.83(0.89-3.78)$ & $1.42(0.50-4.01)$ & $1.92(0.59-6.31)$ & $0.81(0.11-6.07)$ \\
\hline Supplemental vitamin AD user $=$ yes & $2.9 / 3.9 / 3.1 / 3.1 / 3.1$ & $1.42(0.74-2.73)$ & $1.04(0.41-2.67)$ & $1.12(0.33-3.74)$ & $0.95(0.22-5.75)$ \\
\hline Supplemental multivitamin use $=$ yes & $4.7 / 6.3 / 6.2 / 3.1 / 10.8$ & $1.51(0.91-2.51)$ & $1.43(0.73-2.79)$ & $0.72(0.22-2.28)$ & $2.51(1.10-5.75)$ \\
\hline
\end{tabular}

All models adjusted for age, sex, smoking (current smoker yes or no; number of cigarettes per day; number of smoking years), BMI and history of hypertension

Supplemental vitamin C, E, AD and multivitamin use are in one model. *Percentage exposed: subcohort/RCC/clear-cell RCC/clear-cell RCC $V H L$ gene mutated/clear-cell RCC wildtype

However, from our validation study it was concluded that the questionnaire could satisfactorily rank subjects according to the intake of vitamins [26]. Carotenoids could not be assessed in this validation study because the food composition tables for carotenoids were not available at that time. However, for vegetable and fruit consumption, associations have been observed with lung [39] and colorectal [40] cancer within the NLCS. Since vegetables are the main source of carotenoids (with the exception of betacryptoxanthin), these results show that the validity appeared to be sufficient to detect associations. However, this was less clear for previous studies on carotenoids and vitamins within the NLCS [41-44]. If misclassification has occurred, we expect this to be nondifferential and risk estimates are most likely biased towards the null value. This may explain our negative results. The assessment of intake of vitamin supplements was also shown to be reasonably good in our study [32].

We cannot exclude the possibility that residual confounding has influenced our results, even though we tried 
to investigate and adjust for the appropriate confounding factors. All possible confounding factors as reported from the literature and measured within the cohort were included in the analyses if associated with RCC risk and correlated with at least one of the exposure factors in our population. Chance may have played a role since a large number of associations was tested, but we hardly observed statistically significant associations.

Finally, power may have been a problem since the number of cases in subgroup analyses was sometimes low, although results across quintiles did not point in the direction of a dose-response relationship. This prospective cohort study, the third to report on carotenoids, vitamins and supplement intake, was based on 314 incident RCC cases after 11.3 years of follow-up (284 cases with complete data in multivariable analyses). The Iowa Women's Health Study [10] was the first cohort study to report on carotenoids, vitamins and supplement use, analyzing 124 incident cases after 15 years of follow-up. Recently, a report on the Nursus Health Study and the Health Professionals study with results on 132 women and 116 men, respectively, was published [11].

For carotenoids, there was an indication for a u-shaped association with RCC. This was less clear in the case groups of clear-cell RCC, and clear-cell RCC with or without a $V H L$ gene mutation, possibly because of the smaller number of cases. This observation is in line with the observation of a u-shaped association with higher mutation frequencies at lower and higher intakes of dietary carotenoid intake [8]. Despite these suggestive results, we only observed a statistically significant inverse association in quintile 2 of lutein + zeaxanthin intake. For lycopene and beta-cryptoxanthin, risks seemed to be increased, without an indication of a u-shaped association. Lycopene is mainly derived from tomatoes, and citrus fruits including mandarins are an important source of beta-cryptoxanthin. Both tomato consumption and mandarin consumption were associated with a increased RCC risk in our population [37]. We could not explain the previously observed results for tomato and mandarin consumption and ascribed them to chance. Most results for carotenoids were not statistically significant, leading us to conclude that there was no association with RCC risk.

These results are in line with most other studies, which reported statistically non-significant inverse and null associations [10, 14, 18-20]. Two studies reported statistically significant inverse associations. A large population based case-control study including 1,204 cases found a statistically significant inverse association for alpha-carotene, beta-carotene, lutein, and beta-cryptoxanthin [13]. A recent cohort study found that individual carotenoids except lycopene were significantly associated with a lower risk of renal cell cancer in men only [11].
We observed no association of dietary vitamin intake and RCC risk. A statistically non-significant inverse association has been found for folate [20]. For vitamins A and $\mathrm{E}$, mostly null associations and non-statistically significant inverse associations have been reported $[10,11,13,14,19$, 20], although in one study a statistically significant inverse association with vitamin $\mathrm{E}$ intake was found [20]. For vitamin $\mathrm{C}$ intake, reported associations were mostly not statistically significant, but generally somewhat more suggestive of a possible protective effect $[10,11,13,14$, $18,20]$.

Supplemental vitamin E and multivitamin use seemed to be associated with an increased RCC risk (not statistically significant). One trial on vitamin supplementation and RCC risk was carried out (the ATBC study [21]). In this trial, smokers were randomly assigned to supplemental alphatocopherol, beta-carotene, alpha-tocopherol and beta-carotene, or a placebo. No statistically significant differences in incidence/mortality rates of RCC were observed [21]. However, an inverse association was observed with multivitamin supplement use in the Iowa women's health study (RR: 0.63; 95\% CI: 0.42, 0.93) [10]. Two other large population-based case-control studies reported a null association with supplement use [13, 14].

We also investigated possible effect-modification by smoking. We did not observe a differential effect for never, ex and current smokers. Thus far, stronger inverse association for non-smokers [14] as well as non-differential effects [13] has been published. In the study by Hemminki et al. [6], it was noted that smoking appeared to change the outcome of many variables (although smoking itself was not a risk factor for $V H L$ gene mutations). However, small numbers in that study did not allow for testing of smoking as a true effect modifier. In the current study, numbers were also too small to draw firm conclusions from interaction tests and from analyses stratified by smoking.

We were able to investigate risk factors for the specific histological subtype clear-cell RCC and also for the presence of VHL gene mutations, which has not been done before for vitamins and carotenoids. There has only been one report on diet and VHL gene mutations based on a case-only analysis [6]. The authors of that study concluded that their results provide evidence that the intake of vegetables, selenium and particularly citrus fruit protects the renal $V H L$ gene from mutational insults, although chance results could not be ruled out in that relatively small study [6]. Based on case-only comparisons, we would have observed a non-statistically significant protective effect of supplemental multivitamin intake on $V H L$ gene mutations $(\mathrm{OR}=0.22 ; 95 \% \mathrm{CI}: 0.05,1.02)$. However, compared to the subcohort, the risk for wildtype $V H L$ tumors was increased $(\mathrm{RR}=2.51 ; 95 \% \mathrm{CI}: 1.10-5.75)$ which shows that case-only comparisons can be misleading. Thus, we 
observed an increased risk for $V H L$ wildtype clear-cell tumors for supplement use and not a protective effect of supplemental multivitamin use on $V H L$ gene mutations.

In summary, no statistically significant dose-response associations were observed. Stratified results by $V H L$ gene mutation showed no statistically significant differential effects, although results were sometimes suggestive of a differential effect. These associations should be investigated by others to confirm the current observations.

Acknowledgments PAB, RAG and LJS conceived the idea for this study. Paraffin embedded material was collected by BACD. EO and JAS were responsible for the laboratory analyses. CAHK revised all HE-stained slides from collected material. BACD carried out statistical analyses and prepared a first draft of the document. LJS contributed to the interpretation of the data. LJS, EO, CAHK, LALMK, RAG, JAS and PAB revised the document critically for important intellectual content. PAB and RAG also initiated the Netherlands Cohort Study on diet and cancer, of which this study is a part. All authors read and approved the final manuscript. None of the authors had any personal or financial conflicts of interest.We wish to thank Dr. E. Dorant, C. de Brouwer, Prof. Dr. A. Geurts van Kessel and Prof. Dr. D. Ruiter for their preparatory work for this study; Dr. A. Volovics and Dr. A. Kester for statistical advice; S. van de Crommert, H. Brants, J. Nelissen, C. de Zwart, M. Moll, W. van Dijk, M. Jansen and A. Pisters for assistance; H. van Montfort, T. van Moergastel, L. van den Bosch and R. Schmeitz for programming assistance; and $\mathrm{K}$. van Houwelingen and $\mathrm{H}$. Gorissen for laboratory assistance. The authors also thank the staffs of the Dutch regional cancer registries and the Netherlands national database for pathology (PALGA) for providing incidence data. Finally, we would like to thank the participating pathological laboratories for providing paraffin material (for a complete list, see: [33]).Acknowledgment of financial support: this study was financially supported by the Dutch Kidney Foundation (Grant C99.1863) and the Dutch Cancer Society.

\section{References}

1. Gnarra JR, Duan DR, Weng Y et al (1996) Molecular cloning of the von Hippel-Lindau tumor suppressor gene and its role in renal carcinoma. Biochim Biophys Acta 1242:201-210

2. Richards FM (2001) Molecular pathology of von Hippel-Lindau disease and the VHL tumour supressor gene. Expert Rev Mol Med 2001:1-27

3. Kaelin WG Jr (2004) The von hippel-lindau tumor suppressor gene and kidney cancer. Clin Cancer Res 10:6290S-6295S

4. Brauch H, Weirich G, Hornauer MA, Storkel S, Wohl T, Bruning $\mathrm{T}$ (1999) Trichloroethylene exposure and specific somatic mutations in patients with renal cell carcinoma. J Natl Cancer Inst 91:854-861

5. Brauch H, Weirich G, Klein B, Rabstein S, Bolt HM, Bruning T (2004) VHL mutations in renal cell cancer: does occupational exposure to trichloroethylene make a difference? Toxicol Lett 151:301-310

6. Hemminki K, Jiang Y, Ma X, Yang K, Egevad L, Lindblad P (2002) Molecular epidemiology of VHL gene mutations in renal cell carcinoma patients: relation to dietary and other factors. Carcinogenesis 23:809-815

7. Steinmetz KA, Potter JD (1991) Vegetables, fruit, and cancer. II. Mechanisms. Cancer Causes Control 2:427-442

8. Nyberg F, Hou SM, Pershagen G, Lambert B (2003) Dietary fruit and vegetables protect against somatic mutation in vivo, but low or high intake of carotenoids does not. Carcinogenesis 24: 689-696

9. Seifried HE, McDonald SS, Anderson DE, Greenwald P, Milner JA (2003) The antioxidant conundrum in cancer. Cancer Res 63:4295-4298

10. Nicodemus KK, Sweeney C, Folsom AR (2004) Evaluation of dietary, medical and lifestyle risk factors for incident kidney cancer in postmenopausal women. Int J Cancer 108:115-121

11. Lee JE, Giovannucci E, Smith-Warner SA, Spiegelman D, Willett WC, Curhan GC (2006) Intakes of fruits, vegetables, vitamins A, $\mathrm{C}$, and $\mathrm{E}$ and carotenoids and risk of renal cell cancer. Cancer Epidemiol Biomarkers Prev 15:2445-2452

12. Hu J, Mao Y, White K (2003) Diet and vitamin or mineral supplements and risk of renal cell carcinoma in Canada. Cancer Causes Control 14:705-714

13. Yuan JM, Gago Dominguez M, Castelao JE, Hankin JH, Ross $\mathrm{RK}, \mathrm{Yu}$ MC (1998) Cruciferous vegetables in relation to renal cell carcinoma. Int J Cancer 77:211-216

14. Wolk A, Gridley G, Niwa S et al (1996) International renal-cell cancer study. VII. Role of diet. Int J Cancer 65:67-73

15. Chow WH, Gridley G, McLaughlin JK et al (1994) Protein intake and risk of renal cell cancer. J Natl Cancer Inst 86:1131-1139

16. Mellemgaard A, McLaughlin JK, Overvad K, Olsen JH (1996) Dietary risk factors for renal cell carcinoma in Denmark. Eur J Cancer 32a:673-682

17. Lindblad P, Wolk A, Bergstrom R, Adami HO (1997) Diet and risk of renal cell cancer: a population-based case-control study. Cancer Epidemiol Biomarkers Prev 6:215-223

18. Boeing H, Schlehofer B, Wahrendorf J (1997) Diet, obesity and risk for renal cell carcinoma: results from a case control-study in Germany. Z Ernahrungswiss 36:3-11

19. Maclure M, Willett W (1990) A case-control study of diet and risk of renal adenocarcinoma. Epidemiology 1:430-440

20. Bosetti C, Scotti L, Dal Maso L, Talamini R, Montella M, Negri E, Ramazzotti V, Franceschi S, La Vecchia C (2006) Micronutrients and the risk of renal cell cancer: A case-control study from Italy. Int J Cancer 120:892-896

21. Virtamo J, Edwards BK, Virtanen M et al (2000) Effects of supplemental alpha-tocopherol and beta-carotene on urinary tract cancer: incidence and mortality in a controlled trial (Finland). Cancer Causes Control 11:933-939

22. Van den Brandt PA, Goldbohm RA, Van 't Veer P, Volovics A, Hermus RJ, Sturmans F (1990) A large-scale prospective cohort study on diet and cancer in The Netherlands. J Clin Epidemiol 43:285-295

23. Volovics A, van den Brandt PA (1997) Methods for the analyses of case-cohort studies. Biom J 39:159-214

24. Van den Brandt PA, Schouten LJ, Goldbohm RA, Dorant E, Hunen PM (1990) Development of a record linkage protocol for use in the Dutch Cancer Registry for Epidemiological Research. Int J Epidemiol 19:553-558

25. Goldbohm RA, Van den Brandt PA, Dorant E (1994) Estimation of the coverage of Dutch municipalities by cancer registries and PALGA based on hospital discharge data. Tijdschr Soc Gezondheidsz 72:80-84

26. Goldbohm RA, van den Brandt PA, Brants HA et al (1994) Validation of a dietary questionnaire used in a large-scale prospective cohort study on diet and cancer. Eur J Clin Nutr 48:253-265

27. NEVO table (1986) Dutch food composition table 1986-1987. Voorlichtingsbureau voor de Voeding, The Hague

28. Goldbohm RA, Brants HA, Hulshof KF, van den Brandt PA (1998) The contribution of various foods to intake of vitamin A and carotenoids in The Netherlands. Int J Vitam Nutr Res 68:378-383

29. Konings EJ (1999) A validated liquid chromatographic method for determining folates in vegetables, milk powder, liver, and flour. J AOAC Int 82:119-127 
30. Konings EJ, Roomans HH, Dorant E, Goldbohm RA, Saris WH, van den Brandt PA (2001) Folate intake of the Dutch population according to newly established liquid chromatography data for foods. Am J Clin Nutr 73:765-776

31. Voorrips LE, Goldbohm RA, Brants HA et al (2000) A prospective cohort study on antioxidant and folate intake and male lung cancer risk. Cancer Epidemiol Biomarkers Prev 9: 357-365

32. Dorant E, van den Brandt PA, Goldbohm RA, Hermus RJ, Sturmans F (1994) Agreement between interview data and a selfadministered questionnaire on dietary supplement use. Eur J Clin Nutr 48:180-188

33. van Houwelingen KP, van Dijk BAC, Hulsbergen-van de Kaa CA et al (2005) Prevalence of von Hippel-Lindau gene mutations in sporadic renal cell carcinoma: results from The Netherlands cohort study. BMC Cancer 5(1):57

34. Eble J, Sauter G, Epstein J, Sesterhenn I (2004) World Health Organization classification of tumours. Pathology and genetics. Tumours of the urinary system and male genital organs. IARC Press, Lyon

35. Schoenfeld D (1982) Partial residuals for the proportional hazards regression model. Biometrika 69:239-241

36. Lin DY, Wei LJ (1989) The robust inference for the Cox proportional hazards model. J Am Stat Assoc 84:1074-1078

37. van Dijk BA, Schouten LJ, Kiemeney LA, Goldbohm RA, van den Brandt PA (2005) Vegetable and fruit consumption and risk of renal cell carcinoma: Results from the Netherlands cohort study. Int J Cancer 117(4):648-654
38. Goldbohm RA, van 't Veer P, van den Brandt PA et al (1995) Reproducibility of a food frequency questionnaire and stability of dietary habits determined from five annually repeated measurements. Eur J Clin Nutr 49:420-429

39. Voorrips LE, Goldbohm RA, Verhoeven DT et al (2000) Vegetable and fruit consumption and lung cancer risk in the Netherlands Cohort Study on diet and cancer. Cancer Causes Control 11:101-115

40. Voorrips LE, Goldbohm RA, van Poppel G, Sturmans F, Hermus RJ, van den Brandt PA (2000) Vegetable and fruit consumption and risks of colon and rectal cancer in a prospective cohort study: The Netherlands Cohort Study on diet and cancer. Am J Epidemiol 152:1081-1092

41. Schuurman AG, Goldbohm RA, Brants HA, van den Brandt PA (2002) A prospective cohort study on intake of retinol, vitamins $C$ and $\mathrm{E}$, and carotenoids and prostate cancer risk (Netherlands). Cancer Causes Control 13:573-582

42. Verhoeven DT, Assen N, Goldbohm RA et al (1997) Vitamins C and $\mathrm{E}$, retinol, beta-carotene and dietary fibre in relation to breast cancer risk: a prospective cohort study. Br J Cancer 75:149-155

43. Zeegers MP, Goldbohm RA, van den Brandt PA (2001) Are retinol, vitamin $\mathrm{C}$, vitamin $\mathrm{E}$, folate and carotenoids intake associated with bladder cancer risk? Results from the Netherlands Cohort Study. Br J Cancer 85:977-983

44. Botterweck AA, van den Brandt PA, Goldbohm RA (2000) Vitamins, carotenoids, dietary fiber, and the risk of gastric carcinoma: results from a prospective study after 6.3 years of follow-up. Cancer 88:737-748 